\title{
Giftedness among School Children: A Review
}

\author{
Kiran N C ${ }^{1 *}$, C. G. Venkatesha Murthy ${ }^{2}$
}

\section{ABSTRACT}

The present paper has attempted to present a review of issues concerning the education of the gifted children. It has presented concerns and the essence of different models of giftedness and raised issues about the assessment of giftedness. It also has proposed different components of academic task commitment, derived from Renzulli's Three Ring Model and defined them apart from identifying different components they have. It has also presented the gifted programs in India which is an assorted attempt. It has identified gaps and proposed agenda for the imminent future.

Keywords: Giftedness, School, Children, Review

\section{[A] Background:}

The term gifted and talented is often used in tandem to describe a wide range of human exceptional performance. Children to be identified as gifted and talented need to possess needed potential and demonstrate outstanding performance. The term gifted children has a connotation that the outstanding potential they demonstrate is largely a natural endowment. However, the term gifted as used in educational contexts (e.g., gifted child or gifted performance) is descriptive rather than explanatory.

'The phenomenon of gifted and talented children is easier to describe than explain. Some scholars in the field attribute children's outstanding performance on IQ or culturally defined domains largely to their constitutional makeup (e.g., a neurological advantage), reminiscent of the position of Galton (1822), an early pioneer of behavioral genetics and intelligence testing. Other scholars are more cautious about bestowing the title of gifted and talented for some children by mere virtue of their test performance while treating the rest as non-gifted. Rather, they emphasize the emergence of gifted and talented behaviors among children in more authentic contexts as a result of both genetic and environmental influences, involving motivational as well as cognitive processes. Still others point out that, to the extent that the phenomenon of the gifted

\footnotetext{
${ }^{1}$ Research Scholar, Regional Institute of Education (NCERT), Mysore, India

${ }^{2}$ Professor, Regional Institute of Education (NCERT), Mysore, India

*Responding Author

(C) 2016 I N Kiran, V Murthy; licensee IJIP. This is an Open Access Research distributed under the terms of the Creative Commons Attribution License (http://creativecommons.org/licenses/by/2.0), which permits unrestricted use, distribution, and reproduction in any Medium, provided the original work is properly cited.
} 


\section{Giftedness among School Children: A Review}

and talented is subject to different interpretations and assessment strategies based on one's values and beliefs, consequently with different criteria and outcomes, it reflects a social construction rather than an objective reality' (As cited in http://education.stateuniversity.com/pages/2009/ Gifted-Talented-Education.html).

The first step in addressing the definitions of gifted education is its controversial issues, laborious process and sensitive understanding itself. Balchin (2008) has pointed out that Gifted education is a worldwide concern and, although there is no internationally accepted definition of 'giftedness', there is consensus that there is a wide range of students with gifted learning needs in any given school or country. Even Merry (2008) pointed out that developing appropriate definitions of giftedness is important not only to understand better its nature, but also in order to be able to design better educational provisions.

Francis Galton defines a gifted as 'a person who has demonstrated exceptional talent in some area' (Galton, 1869). Later the eminent researcher Lewis Terman (1925) had known as the father of gifted education, defined children with IQs of 150 or more as being gifted; which is fewer than $2 \%$ of all children. While, Renzulli (1978) defines giftedness as "A combination of different cognitive components: high intellectual ability, creativity and task commitment”.

Historically, a seminal report authored by Sydney Marland profoundly influenced how giftedness was conceptualized and defined. According to Marland, (1972) "Gifted and talented children are those identified by professionally qualified persons who by virtue of outstanding abilities are capable of high performance. These are children who require differentiated educational programs and/or services beyond those normally provided by the regular school program in order to realize their contribution to self and society.......... Children capable of high performance include those with demonstrated achievement and/or potential ability in any of the following areas, singly or in combination:

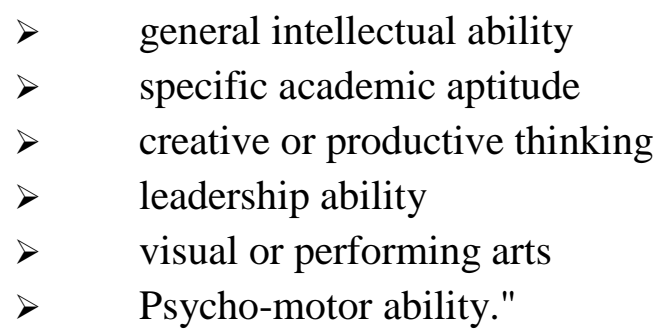

The above definitions do inform and influence us that there are children who require differentiated educational programs and services beyond those that are normally provided by the regular school program in order to realize their contribution to self and society. 


\section{[B] Essence of Different Models influencing Giftedness}

\section{[a] Robert Sternberg's Triarchic Theory of Successful Intelligence (1988)}

Robert Sternberg's Triarchic theory of Successful Intelligence (1988; 1997) states that intelligent behavior results from a balance among analytical, creative and practical abilities. Therefore, it is a collective function of these abilities that allows an individual to achieve success within a particular socio-cultural context. According to Sternberg (1985, 1988, 1997, 1999) "there are multiple loci of intellectual giftedness. Giftedness cannot possibly be captured by a single number. Unless we examine the multiple source of giftedness, we risk missing identification of large numbers of gifted individuals.” Therefore it is one of the important models to consider for the process of identification gifted individuals.

\section{[b] Gagne's Differentiated Model of Giftedness and Talent (DMGT) (2000)}

'The DMGT model is developmental in nature as it posits that talent development corresponds to the transformation of outstanding natural gifts into the skills characteristic of a particular occupational field' (Gagné, 2005). Gagné argues that giftedness (or aptitudes) can be described as natural ability in a particular domain, whereas talent (or achievement) is systematically developed skills in a particular talent field (Gagné, 1999). Natural abilities or aptitudes act as the "raw material" or the constituent elements of talents (Gagné, 1993). Gagné holds a position that those who belong to approximately the top ten per cent of the relevant reference group in terms of aptitudes (for giftedness) or achievement (for talent) merit the label gifted or talented.

'On the talents side are systematically developed skills such as academics, leisure, technology, arts, social action, business, technology, and athletics. During the course of the development of gifts into talents, the DMGT model consists of four components that help represent the talent development process. These include three catalysts: (a) intrapersonal catalysts, (b) environmental catalysts, and (c) chance and (d) learning/practice. Catalysts are defined as elements that contribute to the final gifted product.

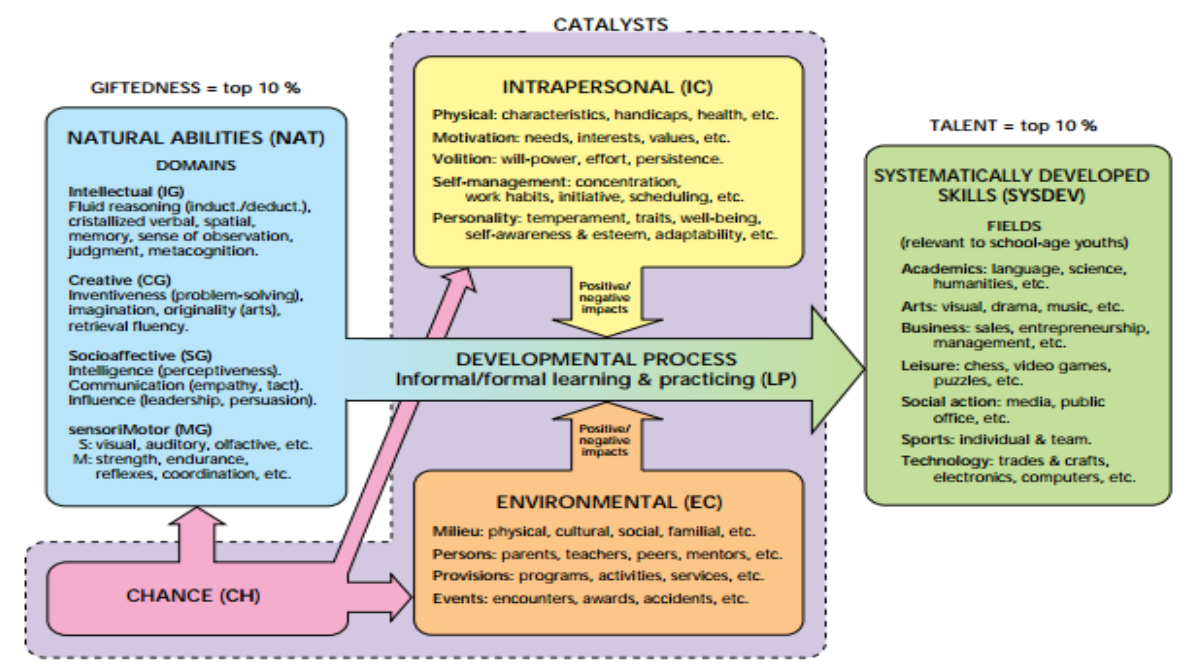

Gagne's Differentiated Model of Giftedness and Talent 


\section{Giftedness among School Children: A Review}

They also vary to the degree which they (a) make a positive or negative contribution to the final product and (b) make a causal impact on the developmental process' (Kaufman,et al., 2009, p.7).

\section{[c] Joseph Renzulli's Three-Ring model (1978)}

The scope of giftedness further gave prominence for performance based measures as well. One of the leading American contemporary pioneers in gifted education Renzulli (1978) turned everything topsy- turvey when he shifted the focus from gifted individuals to gifted behavior. He proposed the three - ring model for the components of giftedness, involving interactions among clusters of human traits identified as above-average ability, task commitment, and creativity.

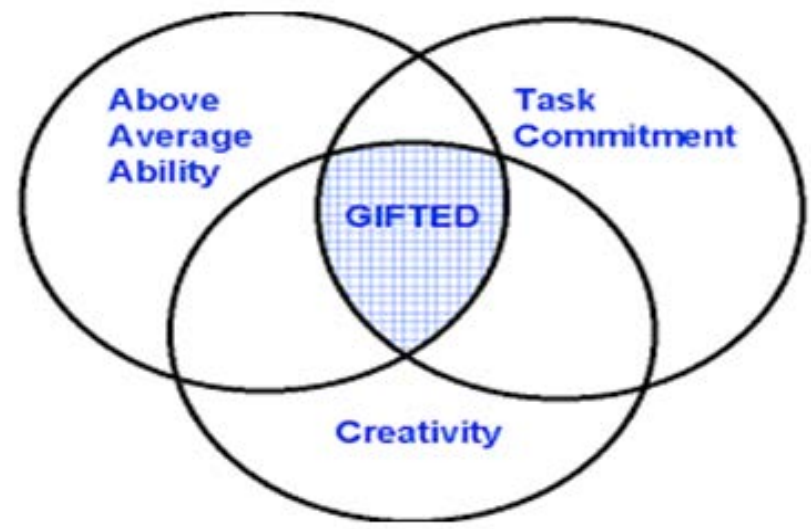

This important work states that gifted individuals show that they possess three particular traits that interlock and affect each other and these three traits constitute giftedness.

\section{[C] Issues related towards assessment of giftedness among school children}

The process of Identification of gifted students has been a challenge to most of the researchers and the initial efforts to create identification processes that would allow trained teachers or staff to locate gifted children who might not have scored high on the regular IQ or achievement tests proved very beneficial. Early work by Renzulli and Hartman (1971, pp. 243-248) and Baldwin (1977) to broaden the process for identifying gifted students gave school districts a much needed alternative to using only IQ or achievement tests to select students thus giving minority students a better chance of being selected.

According to Clarke (1988, pp.620-621) organized identification processes used in school districts classifying them as either used for screening or for identification. She designed an identification matrix, but placed the majority of the processes in the matrix under screening techniques. Few of the alternative forms were placed under identification, which narrowed the choices used to identify giftedness. Although procedures outside of the usual academic or IQ testing are still being suggested as alternatives, a strong dependence remains on the use of IQ tests, as does a belief that they are more relevant for identification techniques. 


\section{Giftedness among School Children: A Review}

In the Indian context, there has been no single measure of assessment of giftedness. The present authors have attempted to theoretically conceptualize assessment of Academic Giftedness based on Renzulli's model. Since there are already available tests on assessment of Intelligence and Creativity, the focus is on the conceptualization of an assessment tool on Task Commitment. Although there is no internationally accepted definition of Task commitment, Renzulli (1978, pp. 5-14) defines it as "The ability of an individual to focus on a task for an extended period of time without distraction". Further, he includes various components of task commitment in his threering model of giftedness which are; High levels of interest, Perseverance, Enthusiasm, Endurance, Self-determination, Hard work and Dedicated practice, Self-confidence, Strong ego fascination, and Drive to achieve. Further he argues that without task commitment high achievement is simply not possible and demonstrated that task commitment is a necessary student variable to perform well in the process-product curriculum model and the concept model may work best with students evidencing high level verbal capacity and broad-based reading behaviors. While, Rena, (2011, pp.3-54) holds that 'Task commitment is best thought of as the constellation of psycho-social variables that translates ability and potential into outstanding performance and there are few studies showing that task commitment contributes to outstanding performance'.

In order to assess academic giftedness, studying academic task commitment is desirable. From this perspective, the present authors taking the cue from Renzulli, have defined Academic Task Commitment as the ability comprising, Endurance, Strong Ego Fascination \& Perseverance, Self Confidence, Interest and Enthusiasm, Self Determination, Hard work and Dedicated Practice. Each of the components has been defined as follows.

(a) Endurance: Refers to the ability to be on high psychological energy levels which facilitates completion of the academic tasks. Its various components include; Memory, Thinking and Reasoning, Problem solving, Language Competence, Planning ability, Ability to evaluate and reflect.

(b) Strong Ego Fascination \& Perseverance: Is the ability to intrinsically feel driven uninterruptedly towards studies and education irrespective of the difficulty levels of the learning tasks. Its various components are Interest, Academic and Intellectual Curiosity, Excitement and Self Drive towards academic activities.

(c) Self Confidence: Is a belief in one's own ability to carry out academic tasks. Its different components are Self esteem, Courage and Imaginability.

(d) Interest and Enthusiasm: Is the ability of the learner to feel, show and demonstrate high energy levels to be engaged in academic tasks. Its components are, Interest towards academic tasks, Thinking constantly about academic activities, Demonstration of interest towards academic tasks, and Pursuing higher levels of academic activities constantly. 


\section{Giftedness among School Children: A Review}

(e) Self Determination, Hard work and Dedicated Practice: Is the ability to plan and implement one's own study habits, with long hours of engagement in learning situations. Its components are Realistic Planning of studies, Effective time management, Focused Attention to the planned activities, Self discipline, and Accomplishment of planned activities.

The above conceptualization would help in developing Academic Task Commitment scale which when used in conjunction with Intelligence tests and Creativity Test would be able to identify academically gifted students in schools. Efforts are on in this direction by the present authors.

\section{[D] Educational programmes for the Gifted in India}

In its report Indian Education Commission (1964-66) criticized segregation and hence did not have a favorable opinion to consider having separate education for gifted. Kothari Commission, made many valuable recommendations including a few about gifted-education. It admitted the importance of enrichment programs and vacation programs. Later In 1986 the government of India realized the need for widening horizons for rural talented students by establishing 'Navodaya Vidyalayas' which is now called 'Jawahar Navodaya Vidyalayas' in India. Quality, Social Equity and Excellence are the three pillars on which it was conceptualized. These are residential school located one in every district. All facilities are provided. Perhaps this is one of the most successful experiments in Education in India. Perhaps, what needs to be explored here is to see whether the selected rural talented students are being nurtured to their full. Thus is an agenda before researchers in India.

There are some public schools in Delhi such as Navyug Vidyalaya and Vidya Niketan schools, Satbadi School and Mirambika school of Auribindo Ashram Delhi are schools which attempt to work as schools meant for the talented and gifted. The Netturhut in Bihar is another one which belongs to this category. The criteria of selection for these schools are not the same. There are some schools, run by non-governmental agencies, all over India, each one implementing its own criteria for selection and picking up the creamy layer of society. All of them have major focus on academic excellence.

Jnana Prabodhini Institute of Psychology at Pune, in Maharashtra was set up with special intention to impart enriched educational programme by segregating the intellectually gifted students after passing standard 4. The institute has been conducting after-school classes in the evening for selected gifted from secondary and higher secondary schools. During 1969, a special high school for gifted was started, which provided an altogether different pattern of school education. It was fashioned on Guilfords's (1967) structure of Intellect (SOI) model. They recruit 80 students per year both boys and girls comprising of 40 each for their school. It emphasizes

enrichment to nurture multiple facets of intelligence and personality. The selection of students is based on a battery of standardized intelligence tests. 


\section{Giftedness among School Children: A Review}

The National Institute of Advanced Studies (NIAS)'s Gifted Children's Program supported by the Principal Scientific Advisor's office (PSA) to the Government of India, is the first collaborative attempt in Indian to draw together a research base to address the issue of Gifted and to develop talent through its channel. The project has developed through a series of consultation meetings starting in 2010 with the Indian National Science Academy's (INSA) INDO-US Forum.

In the joint venture with Delhi University, headed by Jyoti Sharma, Agastya International Foundation, and the National Institute of Advanced Studies under the leadership of Anitha Kurup came together to undertake collaborative research in different areas of the program. The NIAS component of the program involved a multi-pronged approach with a focus on early identification between the ages of 3-8 years from urban backgrounds. Three important areas were identified for the project. The first was a detailed, in-depth set of classroom observations. Second a series of teachers' workshop which was planned as a platform to collaborate with teachers in order to develop insights into issues concerning gifted students. The third component was a set of case studies of children identified as' Gifted' and demonstrating high level pathways of giftedness.

Presumably we still have many unknown gifted and talented students who may be walking, moving in front of our eyes gone un- noticed. Therefore there is a need for identifying such human resources which needs to be carefully identified, nurtured and enabled to blossom to their best, which is the responsibility of the intellectual society and humanity at large.

\section{[E] Gaps and agenda for the imminent future:}

Education of the Gifted and the Talented is the responsibility of any concerned society. There are indeed many interventions taking place in different parts of the world. India is in infancy stage on this issue. Indeed there is a need to have an educational policy articulated well to focus our attention on the above agenda.

In the absence of a universally accepted common definition of giftedness and talent perhaps this area has remained green yet. There is a need for bold pronouncements and proposals, by educational planners, administrators and educational researchers and initiatives with professional training and rigor by practitioners in identifying and nurturing the gifted and the talented students.

Conceptualizing a theory of giftedness and developing tools and techniques to identify the gifted and the talented is the need of the hour. Though there are some assorted attempts in India, it is still not a priority area. This needs attention urgently. 


\section{Giftedness among School Children: A Review}

Further, pre-service teacher preparation programs and in service teacher training programs need to focus issues and concerns about the education of the gifted. Different training strategies proposed and used in different parts of the world need to be understood and adopted in the Indian context and suitably these children need to be trained.

Ultimately, it is the responsibility of all of us in working towards making gifted education a reality by design. No nation can afford to under-utilize the potentialities of its citizens. Therefore, all of us need to promote the idea of the education of the gifted and the talented with all its prerequisites in place.

Note: The present paper was presented in $51^{\text {st }}$ National and $20^{\text {th }}$ International Conference of the Indian Academy of Applied Psychology (IAAP) $6^{\text {th }}-8^{\text {th }}$ may, 2016 organized by Department of Psychology held at Jnana Bharathi, Bangalore University, Bengaluru, and Karnataka, India.

\section{REFERENCES}

Ambrose, D., Cohen, L.M. \& Tannenbaum, A.J. (ed.) (2003). Creative intelligence: Toward theoretic integration. cresskill, NJ: Hampton.

Anastasi, A., \& Urbina, S. (1997). Psychological Testing (7th Ed.). Upper Saddle River, NJ: Prentice Hall.

Angela, C. (2007). Distinguishing Levels of Giftedness: What Does it Mean for our Practice? State of New South Wales through the NSW Department of Education and Training. Neals, p.3-7.

Anitha, B. K. (2013). An introductory reading on giftedness in children. Bangalore: Aditi Enterprises.

Baldwin, A. Y. (1984). Baldwin identification matrix for the identification of gifted and talented.

Baldwin, A.Y. (1977). Tests do under predict: A case study. Phi Delta Kappan, 58, 620-621.

Bhatia, C.M. (1995). Performance tests of intelligence under Indian conditions. Oxford University Press.

Bloom, B. (1985). Developing talent in young people. New York, NY: Balantine.

Clark, B. (1988). Growing up gifted (3rd. ed.). Columbus, OH: Merrill Publishing Company.

Clark, B. (2002). Growing up gifted ( $6^{\text {th }}$ Ed.). New Jersey: Pearson Publication, Inc.

Cruickshank, W. M. \& Johnson, G. O. (1975). Education of exceptional children and youth. Upple Saddle River: Prentice Hall.

Diaz, E. I. (1998). Perceived factors influencing academic underachievement of talented students of Puerto Rican descent. Gifted Child Quarterly, 42(2).

Gross, M.U.M. (1998). Issues in assessing the highly gifted. Understanding Our Gifted, Winter, 3-8.

Guilford, J. P. (1967). The nature of human intelligence. New York: McGraw-Hill.

Hansen, J.B. (1992). Discovering highly gifted students. Understanding Our Gifted, 4(4), 7-13. 


\section{Giftedness among School Children: A Review}

Hebert, T. P., \& Beardsley, T. M. (2001). Jermaine: A critical case study of a gifted black child living in rural poverty. Gifted Child Quarterly, 45(2), 85-103.

Hollingworth, L. S. (1931). Gifted children: Their nature and nurture. New York, NY:Macmillan.

Jason, D. \& Jones, G. (2002). Black bottom stomp. New York, NY: Routledge.

Johnson, D. (1979). The creativity checklist. Wood Dale, IL: Stoelting.

Khatena, J. \& Torrance, E. (1976). Khatena-Torrance Creative Perception Inventory. Chicago, IL: Stoelting.

Kirschenbaum, R. J. (1998). Dynamic assessment and its use with underserved gifted and talented populations. Gifted Child Quarterly, 42(3), 140-147.

Kulik, J.A. \& Kulik, C.C. (1984). Effects of accelerated instruction on students. Review of Educational Research, 54(3). 409-425.

Landvogt, J. (2001). Affecting eternity: Teaching for talent development. Roeper Review, 23(4). 190-196.

Lerner, R. M. (1984) On the nature of human plasticity. New York: Cambridge University Press.

Little, T.D., Bovaird, J.A. and Widaman, K.F. (2006). On the merits of orthogonalizing powered and product terms: implications for modeling latent variable interactions. Structural Equation Modeling, 13, pp. 479-519.

Maithreyi R., Amita B., and Ajay, C. (2013). Case Profiles of gifted children. Bangalore: Aditi Enterprises.

Mattimore, B. (1994). 99\% inspiration. New York, NY: Amacom.

Maurice, F. (1961). Gifted children their psychology and education. New York, NY:Macmillan.

Millar, G. W. (2002). The Torrance kids at midlife. Westport, CT: Ablex.

New York: Royal Fireworks.

Proctor, T.B., Black, K.N. \& Feldhusen,J.F. (1986). Early admission of selected children to elementary school: A review of the research literature. Journal of Educational Research, 80(2), 70-76.

Rena, F. (2011). Rethinking Giftedness and Gifted Education: A Proposed Direction Forward Based on Psychological Science. Psychological Science in the Public Interest, 12, 3-54.

Renzulli J., \& Hartman, R. (1971). Scale for rating behavioral characteristics of superior students. Exceptional Children, 38, 243-248.

Renzulli, J. S. (1978). Systems and models for developing programs for the gifted and talented. Mansfied Center, CT: Creative Learning Press, 5-14.

Renzulli, J. S. (Ed.). Systems and models for developing programs for the gifted and talented. Mansfied Center, CT: Creative Learning Press.

Rogers, K.B. (2002). Re-forming gifted education: Matching the program to the child. Scottsdale, AZ: Great Potential Press Inc.

Rostan, S. (1998). The study of the development of young artists: The emergence of an artistic and creative identity. Journal of Creative Behavior, 32, 278-301. 


\section{Giftedness among School Children: A Review}

Russ, S. (2003). Creativity research: Whither thou goest. Creativity Research Journal, 15, 143145.

Scott, M. S., Deuel, L. S., Jean-Francois, B., \& Urbano, R. C. (1996). Identifying cognitively gifted ethnic minority children. Gifted Child Quarterly, 40(3),147-153.

Southern, S. T., Jones, E. D. \& Southern, W. T. (1991). The academic acceleration of gifted children. New York: Teachers College Press.

Southern, W.T., Jones, E.D. \& Stanley, J.C. (1993). Acceleration and enrichment: the context and development of program options. In K.A.Heller,F.J. Monks, A.H. Passow (Eds) International handbook of research and development of giftedness and talent. New York: Pergamon Press.

Sujala, V.W. (2008). Intellectually gifted adults: Life accomplishment. Bulgarian Journal of Science and Education Policy, 2, 2.

Tomlinson, C. A., Callahan, C. M., \& Lelli, K. M. (1997). Challenging expectations: Case studies of high potential, culturally diverse young children. Gifted Child Quarterly,41(2), 5-18.

Torrance, E. P. (1958). Talent and education. Minneapolis: The University of Minnesota.

Torrance, E. P. (1966). Torrance tests of creative thinking: Norms-technical manual. Princeton, NY: Personnel Press.

Torrance, E. P. (1969). Curiosity of gifted children and performances on timed and untimed tests of creativity. Gifted Child Quarterly, 13, 155-158.

Torrance, E. P. (1995). Why fly? A philosophy of creativity. Norwood, NJ: Ablex

Torrance, E. P. (2002). The manifesto: A guide to developing a creative career. Westport, CT: Ablex.

Van Tassel-Baska, J. (1992). Educational decision making on acceleration and grouping. Gifted Child Quarterly, 36(2). 187-191.

Vygotsky, L. S. (1978). Mind in society: The development of higher mental processes. Cambridge, MA: Harvard University Press.

Wallach, M. (1976). Tests tell us little about talent. American Scientist, 64, 57-63.

Wallach, M., \& Kogan, N. (1965). Modes of thinking in young children. New York, NY: Holt, Rinehart \& Winston.

Weisberg, R. (1986). Creativity, genius, and other myths. New York, NY: W. H. Freeman.

Williams, F. (1980). Creativity assessment packet. Buffalo, NY: DOK.

Yau, C. (1991). An essential interrelationship: Healthy self-esteem and productive creativity. Journal of Creative Behavior, 25, 154-161.

Web Sources:

Gagne Differentiated Model of Giftedness and Talent. Retrieved from http://www.curriculumsupport.education.nsw.gov.au/policies/gats/assets/pdf/poldmgtcolr diag.pdf

Giftedness and the Gifted: What's It All About?. Retrieved from.

(C) The International Journal of Indian Psychology, ISSN 2348-5396 (e)| ISSN: 2349-3429 (p) | 128 
http://www.kidsource.com/kidsource/content /giftedness_and_gifted.html

Gifted and Talented Education The Nature and Identification, Retrieved from. http://education.stateuniversity. com/pages/2009/Gifted-Talented-Education.html

Kaufman, J. C. (2009). Creative giftedness: beginnings, developments, and future promises. Retrieved from. http://scottbarrykaufman.com/wp-content/uploads/2011/06/KaufmanKaufman-Beghetto-Kaufman-Persson-2009.pdf

Nature of giftedness. Retrieved from. http:/www.freepatentsonline.com/article/ExceptionalChildren /59017865.html

How to cite this article: N Kiran, V Murthy (2016), Giftedness among School Children: A Review, International Journal of Indian Psychology, Volume 3, Issue 3, No. 11, DIP: 18.01.202/20160303, ISBN: 978-1-365-21307-6 